\title{
'The mystery of husbandry': medieval animals and the problem of integrating historical and archaeological evidence
}

\author{
UMBERTO ALBARELLA *
}

\begin{abstract}
Archaeological evidence and historic records are often at variance on the subject of animal husbandry. This paper discusses the problems of integrating the evidence for medieval and later Britain, and offers new discussion on the interpretation of the zooarchaeological data.
\end{abstract}

Key-words: Britain, medieval, archaeozoology, husbandry, agrisulture, documents, economy

\section{Introduction}

In 1697 one Leonard Meagre published a general farming treatise entitled The Mystery of Husbandry: or Arable, Pasture and Woodland improved (Fussell 1947). This title is still relevant today as medieval and early modern husbandry are for us in many respects as mysterious as they were in the 17 th century. It also suits the subject of this paper well as there is nothing better to highlight the uncertainty of our knowledge than two sources of evidence which often provide conflicting results.

In this paper I will discuss the problem of comparing and integrating archaeological more specifically 'zooarchaeological' - and historical evidence for medieval and early modern husbandry. I will mainly rely on examples drawn from the research I have carried out, with colleagues, in the last six years in England. However, I hope that some of the methodological aspects of this discussion may be relevant to other geographic areas too.

A few case-studies are presented. We will see that in some cases our data stress the existence of biases, gaps and inconsistencies in either of the two disciplines. In others it will be clear that only through the combined effort of historians and archaeologists will it be possible to solve specific problems. It is also stressed that not all is problematic or incongruous and that cases in which historical and archaeological sources fit well together and provide consistent information do exist. Finally, I briefly discuss what lessons we can learn from the problems and where and how possible solutions are likely to be found.

This paper is written from the point of view of the zooarchaeologist; thus I have no claim to tackle these problems in a completely objective way. Criticisms from historians, other archaeologists and fellow zooarchaeologists are welcome. My ultimate aim and hope is to stimulate some debate and to encourage an exchange of information and ideas.

\section{Counting sheep}

One of the basic tasks of zooarchaeological analysis is to calculate the frequency of different animal species present in an archaeological assemblage. Despite methodological problems in carrying out these quantifications we are able to provide some clues about the relative importance of different animals. $\mathrm{Me}-$ dieval bone assemblages are almost invariably dominated by the bones of cattle, sheep and pig, namely the domestic mammals with the horse - of greatest economic importance. Much more variable - and difficult to assess - is the relative importance of each of these three species.

\footnotetext{
* Department of Ancient History \& Archaeology, University of Birmingham, Edgbaston, Birmingham B15 2TT, England. u.albarella@bham.ac.uk
}

Received 3 December 1998, revised 25 February 1999, accepted 4 May 1999. 


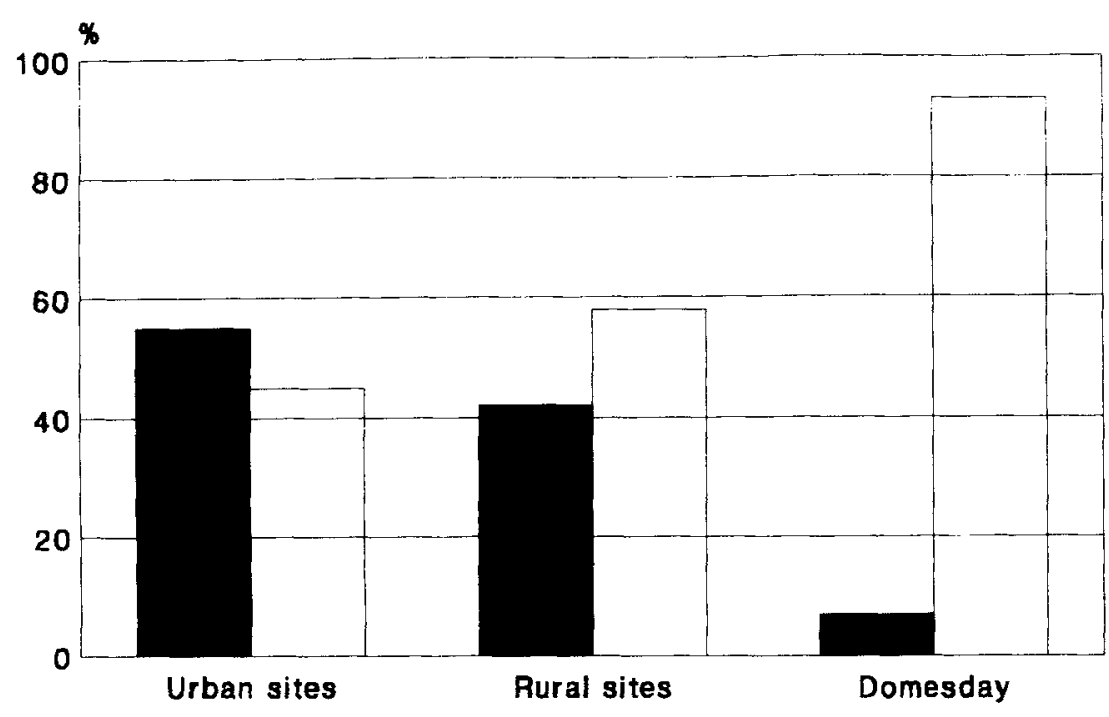

Cattle

\section{Sheep}

FIGURE 1, Average frequency of cattle and sheep bones in English medieval archaeological sites and in the Domesday Survey. The Domesday sites used are listed in TABLE 1. The bone assemblages from archaeological sites range from the 10th to the 14th century AD. 62 assemblages from urban sites and 15 from rural sites have been considered (for details see Albarella et al. 1997).

Although much variation occurs between early and late medieval sites, between urban and rural sites and between sites of different social status (Grant 1988; Albarella \& Davis 1996), cattle and sheep bones tend to be more common than pig bones. The relative distribution of the two most common species is highly variable, but it is probably not totally incorrect to state that, on average, bones of cattle and sheep tend to be equally numerous. However, sheep are generally more frequent on rural sites and cattle in towns (FIGURE 1 ) and sheep increased in number in the later Middle Ages - a change possibly connected to the expansion of land devolved to pasture (Campbell et al. 1996) and to the increasingly flourishing wool market. Regional variation also occurs. Methodological problems can also create much variation in the frequency of the two species; sheep bones are much smaller than cattle bones and on sites where the recovery has been poor sheep tend to be much under-represented. However, despite all these differences it is clear that cases in which either one of these two species is far more common than the other are rare.

During most of the Middle Ages the main concern in cattle and sheep husbandry was unlikely to have been their meat. However, there is also little doubt that almost all animals at the end of their life were eaten and the implications of the archaeological findings are therefore clear. Beef and mutton were both very important, but, due to the much larger size of the cattle carcass, beef was probably eaten in much greater quantity.

So much for the archaeological evidence. However, historic sources tell a different story. Animal counts from a selection of demesnes from the Domesday Book (Morris 1984) are provided in TABLE 1, and their average figure is compared to that deriving from archaeological sites (FIGURE 1). The sample of Domesday farms cannot be taken as representative for the whole country. Moreover, these data derive from seigniorial rather than peasant livestock. However, despite this note of caution, there seems to be little doubt that the Domesday survey suggests that sheep were by far the most common animals at the time of the Norman conquest (Finn 1963), and much more common than is indicated by the archaeological evidence. Although the figures from the Domesday book only include the animals present in the demesne - and not those which belonged to a manor but were kept, for instance, in the wood - (Finn 1963), we are still left with the impression of a landscape dominated by flocks of sheep. Even in areas where cattle husbandry was particu- 
larly important, there was no more than one head of cattle ${ }^{1}$ per seven sheep (Trow-Smith 1957). The average ratio of cattle to sheep as recorded by the Domesday book in Norfolk, Suffolk and Essex is consistently below 1:10 (Hallam 1988).

Data for later periods do not seem to reverse this proportion. In fact in the later Middle Ages sheep numbers increased further (Trow-Smith 1957). At 12th-century Exton (Rutland) there were 23 cattle and 280 sheep (Trow-Smith 1957), whereas 44 cattle and 200 sheep were received by the Archdeacon William from the abbey of St Benet of Holme in 1153-68 (Hallam 1988: 296). Data for the number of animals per taxpayer in the 13th century indicate that in villages in Gloucestershire, Wiltshire and Suffolk there were no more than between 1.3 and 3.5 cattle per 10 sheep (Dyer 1989: 114, 130 \& table 10). Data from the lay subsidy for the hundred of Blackbourne (Suffolk) suggest similar ratios (Hallam 1988: 300), and the proportion of sheep in the same period in Essex seems to have been even higher (Hallam 1988: 304). The figures of average holdings of animals per taxpayer confirm that both in sheep-farming areas, such as Wiltshire, and in mixed farming areas, such as Suffolk, sheep far outnumbered cattle in the 13th century (Postan 1973: 229). In the 14th-century estates of the Bishopric of Worcester, 4638 sheep and only 361 cattle are counted (Dyer 1980) - namely 0.8 cattle per 10 sheep. Late medieval yeomen would keep no more than 20 cattle per 300 sheep (Dyer 1989). Many more examples of this situation can of course be found. As for the earlier period, the general impression that we gain is that the later medieval landscape was much more dominated by sheep than the archaeological evidence suggests.

How can we explain the inconsistency between the two sources? First of all, it must be emphasized that frequencies of different species in living populations and archaeological assemblages (i.e. assemblages of dead animals) cannot be directly compared unless we assume that the average age of death was the same for all species. In other words we must take into account that, for instance, an animal that was slaughtered when four years old would have twice as much chance of being counted in a living population as another that died when it was only two years old. This means that if in

1 Unless otherwise stated figures for cattle include both cows and oxen. site

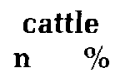

sheep

notes

$\begin{array}{lrrrrl}\text { Norfolk } & & & & & \\ \text { Messigham } & - & 0 & 64 & 100 & \\ \text { Southmere } & 1 & 1 & 87 & 99 & \\ \text { Saham } & 8 & 12 & 60 & 88 & 40 \text { goats } \\ \text { Foulsham } & 12 & 17 & 60 & 83 & 50 \text { goats } \\ \text { Cawston } & 20 & 25 & 60 & 75 & 50 \text { goats } \\ \text { Ormesby } & 4 & 1 & 381 & 99 & \\ \text { Palgrave } & 2 & 5 & 36 & 95 & \\ \text { Newton } & 9 & 23 & 30 & 77 & \\ \text { Horningtoft } & 1 & 1 & 160 & 99 & 20 \text { goats } \\ \text { Cranworth } & 2 & 9 & 20 & 91 & 20 \text { goats } \\ \text { total } & 59 & 6 & 958 & 94 & \end{array}$

Essex

$\begin{array}{lrrrrl}\text { Brightlingsea } & 16 & \mathbf{9} & \mathbf{1 6 6} & \mathbf{9 1} & \\ \text { Newport } & 10 & \mathbf{9} & 102 & \mathbf{9 1} & \\ \text { Bocking } & 6 & \mathbf{6} & 100 & \mathbf{9 4} & \\ \text { Stiisted } & 40 & 25 & 120 & 75 & \\ \text { Corringham } & 6 & 1 & 500 & \mathbf{9 9} & 21 \text { goats } \\ \text { Paslow } & 6 & 11 & 50 & 89 & 36 \text { goats } \\ \text { St Peter's Chapel } & 3 & 1 & 216 & \mathbf{9 9} & \\ \text { Berewic } & 18 & 12 & 126 & 88 & \\ \text { Langenhoe } & 2 & 1 & 300 & 99 & \\ \text { Tolleshunt } & 16 & 4 & 400 & 96 & \\ \text { total } & 117 & 5 & 2080 & 95 & \end{array}$

total

10

\section{Tawton \\ Exminster \\ Crediton \\ Dawlish \\ Sidbury \\ Paignton \\ Slapton \\ Bovey \\ Huish \\ Roborough \\ total}

Cornwall

Binnerton

Burniere

Cargoll

Alverton

Trelawne

Halton

Cosawes

10
4
64
3
10
20
9
30
5
15
170

10

$\begin{array}{rrr}90 & 90 & \\ 120 & 97 & \\ 400 & 86 & 125 \text { goats } \\ 100 & 97 & \\ 140 & 93 & 14 \text { goats } \\ 350 & 95 & \\ 100 & 92 & \\ 85 & 74 & 5 \text { goats } \\ 50 & 91 & \\ 60 & 80 & \\ 1495 & 90 & \end{array}$

$\begin{array}{rrrr}13 & 18 & 60 & 82 \\ 4 & 3 & 150 & 97 \\ 7 & 10 & 60 & 90 \\ 9 & 8 & 100 & 92 \\ 6 & 13 & 40 & 87 \\ 2 & 5 & 40 & 95 \\ 17 & 7 & 240 & 93 \\ & & & \\ & & & \\ 9 & 4 & 232 & 96 \\ 7 & 12 & 50 & 88 \\ 4 & 14 & 25 & 86 \\ 78 & 7 & 997 & 93 \\ 424 & 7 & 5530 & 93\end{array}$

$\begin{array}{lrrrr}\text { Goviley } & 9 & 4 & 232 & 96 \\ \text { Trevague } & 7 & 12 & 50 & 88 \\ \text { Crackington } & 4 & 14 & 25 & 86 \\ \text { total } & 78 & 7 & 997 & 93 \\ \text { grand total } & 424 & 7 & 5530 & 93\end{array}$

12 goats

12 goats

10 goats all sheep are wethers (!)

TABLE 1. Frequencies of caltle and sheep on a selection of sites from the Domesday Book (Morris 1984). 
an archaeological assemblage we have a high number of young animals of one species and a high number of old animals of another species we cannot assume that the relative frequency of these two species reflects what we would have seen in the living populations - this assumption would indeed lead to an overestimate of the species represented by the younger specimens. However, this consideration does not help to solve our problem. At least until the late 15th century most cattle bones found in archaeological assemblages in medieval England belong to mature animals and, if anything, we might suspect that the age factor leads to an underestimation of the cattle numbers.

Zooarchaeologists are aware that there are a number of biases that affect bone assemblages. Bones of different animals can be disposed of, preserved and recovered in different ways and this affects the relative frequency of the species they belong to. Allowances must be made for this variation, especially taking into account the fact that bones of larger animals are less likely to be destroyed by scavengers and, due to their size, are less likely to be missed during archaeological excavations. When studying the animal bones from the Saxon to post-medieval site of Castle Mall (Norwich), the frequency of the main species from the assemblage collected by hand and that collected by sieving were compared. It was clear that many sheep bones were missing from the hand-collected assemblage, but even in the sieved assemblage sheep was at the most as common as cattle (Albarella et al. 1997: table 6). Similar observations carried out on assemblages from other sites have also led to the conclusion that numbers of sheep bones tended to be underestimated, but the ratio between sheep and cattle numbers was still lower than the documents suggest.

Another factor that may affect the number of the animals is a possible differential disposal of the bones of the two species. Sheep were more prone to die of disease (Chris Dyer pers. comm.) and consequently their carcasses may have been disposed of out in the fields and never found by archaeologists. Although this may lead to some underestimation of sheep numbers, it does not seem an important enough factor to explain the remarkable discrepancy between the historical and archaeological data.

A more serious problem may be that we have more abundant documentary evidence for demesnes than for villages. Peasants were likely to own a relatively smaller proportion of sheep than cattle in comparison to the seigniorial demesnes (see Hallam 1988 \& Harvey 1988) and therefore the fact that peasant livestock is somewhat overlooked by the documents may lead to an over-representation of sheep numbers. However, some data from villages are available and they still suggest a clear predominance of sheep upon cattle. Therefore, this is a factor that may reduce the scale of the problem without fully solving it.

It seems that we are left with another mystery. Historic sources suggest that the archaeological evidence is underestimating the importance of sheep in medieval times, but it is not clear why. Better attention to problems of differential disposal, preservation and recovery may help to correct biases and may lead the way to a complete solution of the enigma. It is possible that these factors play a more important role than we have hitherto thought. However, historians should also ponder on this problem and explore the possibility that their evidence might lead to some spurious estimation of cattle or sheep numbers. In particular the fact that different categories of producers are unevenly represented in historical documents may produce a bias in our view of the relative importance of different types of livestock.

\section{Slaughtering and meat disposal}

Bones deriving from all parts of cattle and pig carcasses are generally found in animal-bone assemblages from medieval rural sites in Britain - e.g. Burystead and Langham Road (Davis 1992), Eckweek (Davis 1991), Launditch Hundred (Ambros 1980). This has generally led to the conclusion that both these animals were commonly slaughtered and butchered on site. If selected cuts of meat only were introduced to the site we would indeed expect to find mainly bones of the important joints, which carry more meat, whereas skull and foot elements would be rarer. Some of these sites, such as West Cotton in Northamptonshire (Albarella \& Davis 1994) and North Elmham in Norfolk (Noddle 1980) have animal-bone assemblages from late Saxon, early medieval and late medieval periods, and in both sites no obvious differences in the distribution of body parts of pig and cattle between different periods have been noticed. 
FIGURE 2. Frequency of male and female pig canines at Launceston, Norwich and West Cotton. With its high frequency of females, rural West Cotton is more likely to have been geared towards production than the urban site of Norwich, Castle Mall and the castle at Launceston. Only canines present in jaws have been considered, as the count of isolated teeth may reflect a bias towards the recovery of the larger male canines.

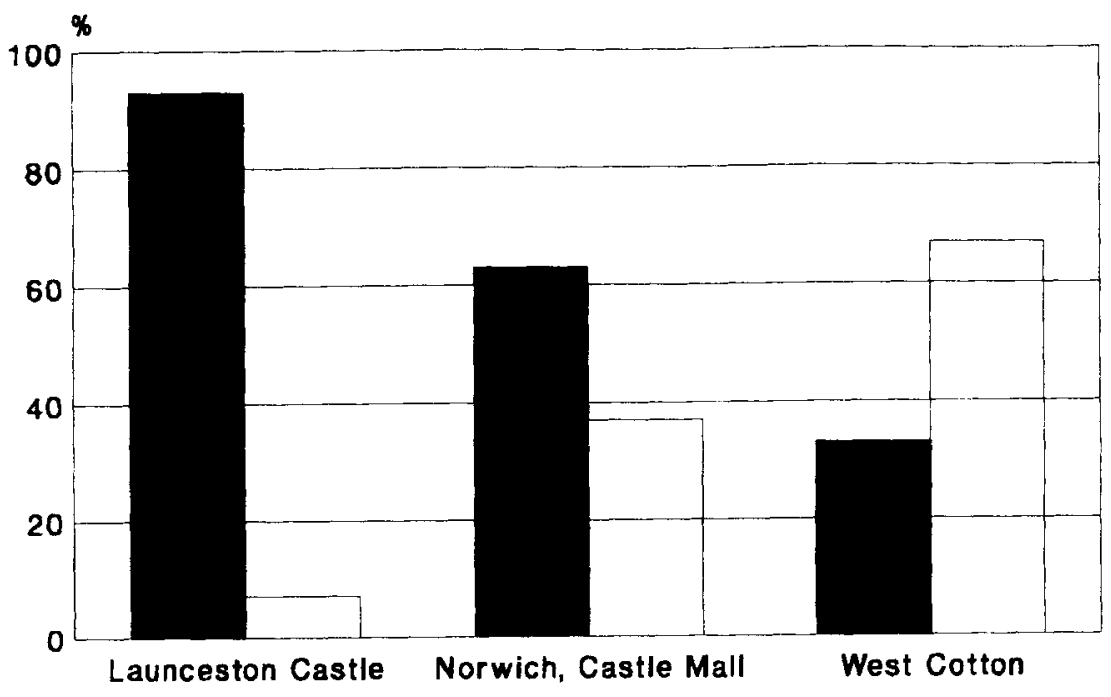

The interpretation of the anatomical evidence as attesting local slaughtering leaves us with the problem of how a family or even a small rural community could dispose of the large amount of meat from the cattle carcass. Even if we take into account the fact that medieval animals were on average smaller than modern improved breeds, a cattle carcass would still have produced between 100 and $200 \mathrm{~kg}$ of edible matter (McCormick in press; Gibson 1988) - a remarkable amount of meat that would have rotted quickly if not consumed within a few days.

One way to deal with the problem would have been to preserve the meat, through salting or smoking. This practice was widely used for pork - bacon was probably the most common meat eaten by people living in rural communities - but it is less commonly attested for beef. In an attempt to explain the virtual absence of salt beef in the Irish and Scottish early documents, McCormick (in press) suggests that a possible explanation is provided by the prohibitive cost of the large amount of salt needed to cure a cattle carcass. The mention in historic documents of a quarter of salt beef in a barrel kept by peasants (Dyer 1989) suggests that beef was cured, but this does not seem to have been as common a practice as for pork. The reference in the literature to "Martinmas

beef' (see Trigg 1990: 12) - i.e. beef salted soon after a November slaughter (Chris Dyer pers. comm.) - and the mention of the slaughter of oxen for the 'larder' in aristocratic household accounts (Redstone 1931: 128) both suggest that the wealthier people may have cured their beef on a regular basis, possibly because they had easier access to salt supply.

An alternative way to dispose of the meat would have been to organize communal feasts. This is how the supposed consumption of large quantities of meat has in some cases been explained for prehistoric (Albarella \& Serjeantson in press) and Roman societies (Lauwerier \& Groenewoudt forthcoming). A more appropriate example derives from the Irish pre-market medieval society. Here feasts were regularly organized when a large animal was slaughtered. Even though people of different status would get different cuts of meat, the refuse would end up together, thus explaining the presence of parts of the skeleton in the archaeological assemblage (McCormick in press).

The evidence for pigs at West Cotton not only indicates that pigs were slaughtered for household consumption, but also that they were raised on site and that some young males were probably reared for sale. The sex ratio on this site reflects the proportion that we would expect 
on a 'producer' site and it is in contrast with what is found on 'consumer' sites, where males are predominant (FIGURE 2). The archaeological evidence for pig seems to be perfectly consistent with what we would expect on a rural site on the basis of the historical sources. However, the situation for cattle is more problematic. We have seen that possible explanations for the disposal of large amounts of meat can be found, but what remains surprising is that also in the late medieval period - when a market economy had become predominant (Dyer 1989; 1994) - we seem to have evidence of slaughter and consumption 'in-house'. On the basis of the documentary evidence we should expect that peasants, at least since the mid 13th century, would take their cattle to the market, and possibly buy back smaller cuts of meat from the butcher (Dyer 1989: 156). But the move to a market oriented economy is not reflected in the archaeological evidence.

Finbar McCormick (pers. comm) has drawn my attention to the possibility that butchers would have had difficulty in disposing of the bones and they would therefore tend to give them to buyers - in our case peasants - who might then have used the marrow or fed the bones to dogs. The high frequency of dog gnawing on the West Cotton bones could be of interest in this respect. However, although this possibility can account for the presence of most post-cranial bones in archaeological assemblages, it seems unlikely that cranial bones and teeth - which have little or no fat and are therefore unpalatable to dogs - could have been used in a similar way. Thus we have to accept the possibility that even in a strongly marketoriented society some villages would have disposed of some of their large animals locally. And we can reach this conclusion only through an integration of the historical and archaeological evidence.

Since market sites were regularly cleaned they tend to produce ephemeral deposits that may be difficult to detect archaeologically. Animals that passed through the market may end up in urban pits and ditches, but the market in itself may represent an almost invisible and sometimes forgotten element of the archaeological evidence. History seems to be troubled by the opposite problem, as it heavily relies on what was bought and sold - which is recorded in household and manorial accounts but it is less informed on what was produced and consumed locally (see for instance Dyer 1997a). The risk is for archaeology to over-emphasize the importance of a self-sufficient economy and for history to place too great an emphasis on the role of the market. The integration of the two approaches may lead to the conclusion that by the 13th century rural communities in Britain had started relying on a market economy but most of the pork (and, of course, mutton) and some of the beef was still home-grown.

\section{The missing animals of the historical record}

One of the problems that most obviously highlights the need for a better integration of the historical and zooarchaeological evidence is represented by the unevenness of the information about different species of animals in both sources. For instance, historical documents tend to neglect animals of little economic value, but which were still important in medieval life.

Although domestic animals such as cattle, sheep, pig and horse play a prominent role in the documents, other species such as dogs and cats are only mentioned in passing. Dogs are mainly mentioned in court cases because they had been used for illegal hunting or because they had bitten people (Hanawalt 1986: 256). However, very little is said about how these animals were used, where they would live and how common they were. In contrast animalbone assemblages from archaeological sites almost invariably include some dog and cat bones, and often burials of these species are also found. Dog gnawing marks on the bones of other animals are even more common - especially in rural sites - and suggest that roaming dogs must have been a typical feature of the medieval scene. All in all the impression that we gain from archaeological sites is that domestic carnivores were far more important than the historical evidence seems to indicate.

Dogs and cats were likely to be kept as pets and to control the spread of commensal rodents (rats and mice). Dogs, of course, would also be used as guard animals and for hunting, but this latter was a privilege mainly restricted to the upper classes. Once dead, these animals would still provide useful products in the form of their pelts. Skinning marks on dog and cat bones are very common on archaeological sites, and in some cases it seems that young cats were killed on purpose to obtain the best-quality skins (McCormick 1988; Luff \& Moreno Garcia 1995). 
Being marketable items dog and cat skins are also mentioned in documents, and we know for instance that dog pelts would be considered a valuable raw product for making gloves (Serjeantson 1989). However, the high frequency of skinning marks on cat and dog bones from rural sites and the scanty documentary evidence for these items suggests that dogs and cats may be neglected by historic sources, not only as concerns the living animals but for their products too.

Although never present on cat bones, butchery marks have been found on dog bones from several medieval assemblages. Their interpretation is debatable and among the possible explanations we may mention the possibilities that dog meat might have been eaten occasionally (Dobney et al. undated), that it would be used for feeding other dogs (Wilson \& Edwards 1993) or that the marrow fat would be exploited for cosmetic or other uses (Gidney 1996). Once again the documents are inconclusive in finding a solution to this problem, although they can provide some clues.

I believe that the case discussed above may be taken as a reminder of the fact that historical sources tend to give much more substantial information about animals that provided a direct contribution to the medieval economy and whose products would become part of a mechanism of sale and purchase. Our analysis of archaeological bone assemblages can help to fill in some of the gaps left by the historic documents and to inform us about aspects of medieval life that are important although not immediately connected to a market economy.

\section{The missing animals of the archaeological record}

Whereas a fairly straightforward explanation can be provided for the omission of some animal species in the historical record, it is more difficult to understand why some animals that are frequently mentioned by the documents turn up so rarely on archaeological sites.

Though the donkey can be mentioned as one such case, the most typical example is probably represented by the goat. The goat - although far less common than the sheep - is frequently mentioned in the Domesday Book; it seems that these animals were even kept in relatively large numbers on some demesnes (TABLE 1). In Suffolk and Essex they were more common than horses and as numerous as cat- tle (Hallam 1988) - the bones of both species are extremely abundant in the archaeological record. Large herds of goats also seem to have been kept in the West Midlands in the 14th century (Dyer 1991) in a period in which the pressure on countryside resources was relaxed as a consequence of the reduction of the population caused by the Black Death. By the end of the Middle Ages goats had become rarer, probably because of the damage they were causing to woods and especially to hedges (Burke 1834: II, 505), whose function had become especially important following enclosure of the land. They also tended to sour restricted pasture and this may have rendered them increasingly unpopular (Harvey 1988). The decline of the goat is also reflected in the archaeological record, as goats are almost completely absent from late medieval and post-medieval sites (Albarella 1997a).

However, goats are not much more common in archaeological assemblages of earlier periods. In other words the goat, throughout the whole medieval period in the British Isles, is much less common on archaeological sites than historical sources suggest it should be. However, it has to be said that this question mainly applies to goat bones and teeth, because horncores - the bony core of bovid horns - of these animals are occasionally found in great abundance on archaeological sites (see for instance Noddle 1977). The quantity of horncores and the scarcity of other parts of the skeleton has even led to the suggestion that there might have existed an independent trade in goat horncores, possibly with overseas countries (Albarella et al. 1997). However, this suggestion, in order to have a firmer basis, has to address the problem of why goat bones are so under-represented on archaeological sites.

In a way the reason why goats are underrepresented in the archaeological record is of secondary importance here, as my main point is to highlight how unwise it would be to rely just on the archaeological evidence and how essential it is to consider these data along with the historical evidence. However, it should be mentioned that goat bones are difficult to distinguish from the bones of much more common sheep. The sorting-out of identification problems is paramount in any attempt to find a solution to the problem of the under-representation of goats in archaeological assemblages. At the same time it would be interesting to see 
if historians think that the documents may in some way give us a wrong impression of the importance of the rarer species - such as the goat - for the medieval economy.

\section{Conclusions}

Each of the problems discussed above would deserve a thorough investigation, extensive research and eventually a separate paper. In this context the cases are presented in order to highlight some of the questions connected with the integration of historical and zooarchaeological evidence in the medieval period. It is for this reason that, although hypotheses have been suggested, I have made no attempt to find a definitive solution to the problems.

What is discussed in this paper is only a sample of a much greater number of cases that can point to the fact that the past relationship of people and animals can only be fully understood through the combined effort of archaeologists and historians. Historic documents and archaeological remains represent important, but incomplete, tools for our understanding of the past. The fact that they sometimes provide complementary information means that they can be seen as pieces of a puzzle that must be viewed together. Although this may seem obvious, a quick browse through the literature can easily show that archaeologists and historians often ignore each other's evidence.

A greater awareness of the incompleteness of the archaeological and historical records may help encourage scholars in both disciplines to fill the gaps using information deriving from a different field. However, problems are likely to remain. Data derived from documents or from archaeological remains need interpretation and should not be read in an uncritical way. For instance, historians need to be aware that data on the frequency of different species, body parts and age groups, generally provided in zooarchaeological reports, can be misleading if taphonomic, recovery and other biases are not taken into account. Similar problems certainly apply to the documentary evidence too. Therefore the use of the data from the other discipline may be insufficient and in some cases may even lead to spurious interpretations.

Since it is difficult to see how researchers, who struggle to keep themselves updated with the large body of information deriving from their own discipline, can get deeply engaged in the nuances of another field, we have to conclude that the only possible way forward is for historians and archaeologists to work in close association. Occasional cases of collaboration do exist and may lead the way to a more interdisciplinary-oriented future. For instance a few research groups, such as the Medieval Settlement Research Group, include both archaeologists and historians (see Dyer 1997b). And the existence of other similar interdisciplinary groups was made clear in a recent debate at the Medieval Europe conference in Bruges (October 1997). However, the most common situation is still of insufficient interchange and isolation. The main medieval conferences tend to be dominated either by historians or by archaeologists but they are rarely shared by both. Most journals, societies and research projects are either for historians or for archaeologists. It is also not entirely unusual to see scholars firmly defend the identity of their own discipline, or show contempt for findings from other fields. Archaeology and history university departments sometimes blatantly ignore each other. These things will not be changed easily or quickly, but an increase in the intensity and quality of communication seems to be an important step for the future of both disciplines.

It is to be hoped that more research projects that involve archaeologists and historians will be funded, that more conferences on common themes will be organized and perhaps that a new journal that deals, on equal levels, with archaeological and historical contributions to medieval agricultural history will appear.

Zooarchaeology and agricultural history use different tools - bone assemblages and documents - but share the same objective of understanding the past. After decades of study we still have substantial uncertainties about the relative importance of different farm animals during the Middle Ages, and we are still debating what was the impact of the market on the animal economy. It is likely that we will continue to discuss these problems in the coming decades, but if we want to make rapid and good progress we will have to ensure that we take part in the debate with an open mind and fully respect the contribution of other disciplines.

Acknowledgements. My deepest gratitude goes to Chris Dyer for a number of interesting conversations that have inspired me to write this paper. I would also like to thank Chris Callow, Bruce Campbell, Marina Ciaraldi, Simon Davis 
Gerald Dawe, Chris Dyer, James Greig, Andy Hammon, Finbar McCormick, Rebecca Roseff, Dale Serjeantson, Richard Thomas and Robin Thornett for helpful comments

\section{References}

ALBARELLA, U. 1997a. Size, power, wool and veal: zooarchaeological evidence for late medieval innovations, in $G$. De Boe \& F. Verhaeghe (ed.), Environment and subsistence in medieval Europe: 19-30. Bruges: Institute for the Archaeological Heritage of Flanders. Papers of the 'Medieval Europe Brugge 1997' Conference volume 9.

Albarella, U., M. BEECH \& J. Mulville. 1997. The Saxon, Medieval and Post-medieval mammal and bird bones excavated 1989-1991 from CastleMall, Norwich (Norfolk). London: English Heritage. AML report 72/97.

Albarella, U. \& S. Davis. 1994. The Saxon and Medieval animal bones excavated 1985-1989 from West Cotton, Northamptonshire. London: English Heritage. AML report 17 94.

1996. Mammals and bird bones from Launceston Castle: decline in status and the rise of agriculture, Circaea 12[1] (1996 for 1994): 1-156.

ALBARELLA, U. \& D. SERJEANTSON. In press. A passion for pork: meat consumption at the British late Neolithic site of Durrington Walls, in Miracle \& Milner (ed.).

AMBros, C. 1980. The mammal bones, in P. Wade-Martins, Fieldwork and excavation on village sites in Launditch Hundred, Norfolk, Eost Anglian Archaeology 10: 158-9.

ASTLL, G. \& A. GRANT (ed.). 1988. The countryside of medieval England. Oxford: Blackwell.

BURKE, J. 1834. British husbandry; exhibiting the farming practice in various parts of the United Kingdom. London: Baldwin \& Cradock.

CAMPBELl, B., K. BARTLEY \& J. POWER. 1996. The demesne-farming systems of post-Black Death England: a classification, Agricultural History Review 4(2): 131-79.

Darby, H. 1977. Domesday England. Cambridge: Cambridge University Press.

DAVIS, S. 1991. Faunal remains from the Late Saxon-Medieval Farmstead at Eckweek in Avon, 1988-1989 excavations. London: English Heritage. AML report 35/91.

1992. Saxon and Medieval animal bones from Burystead and Langham Road, Northants; 1984-1987 excavations. London: English Heritage. AML report 71/92.

DOBNEY, K., D. JAQUES \& B. IRVING. N.d. Of butchers and breeds. Report on vertebrate remains from various sites in the City of Lincoln. Lincoln: City of Lincoln Archaeology Unit. Archaeological Studies 5.

DYER, C. 1980. Lords and peasants in a changing society. The Estates of the Bishopric of Worcester, 680-1540. Cambridge: Cambridge University Press.

1989. Standards of living in the later Middle Ages: social change in England c. 1200-1520. Cambridge: Cambridge University Press.

1991. The West Midlands, in E. Miller (ed.), The agrarian history of England and Wales III: 1348-1500: 222-37. Cambridge: Cambridge University Press.

1997a. Do household accounts provide an accurate picture of late medieval diet and food culture?, in E. RassartEeckhout, J.-P. Sosson, C. Thiry \& T. Van Emelryck (ed.), La vie matérielle au Moyen Age. Liapport des sources littéraires, normatives et de la pratique: 109-25. Louvainla-Neuve: Presses Universitaire de Louvain. Textes, Études, Congrès, vol.18,

1997b. Recent developments and future prospects in research into English medieval rural settlements, in G. De Boe \& F. Verhaeghe (ed.), Rural settlements in medieval Europe: 55-61. Bruges: Institute for the Archaeological Heritage of Flanders. Papers of the 'Medieval Europe Brugge 1997' Conference volume 6 . on an earlier version of this paper. I am also grateful to English Heritage for allowing me to spend time on some of the projects that have led to the writing of this paper.

FinN, R. 1963. An introduction to Domesday Book. Westport (CT): Greenwood Press.

FUSSELL, G. 1947. The old English farming books form Fitzherbert to Tull. London: Crosby Lockwood.

GIBSON, A. 1988. The size and weight of cattle and sheep in early modern Scotland, Agricultural History Review 36: $162-71$.

GIDNEY, L. 1996. The cosmetic and quasi-medicinal use of dog fat, Organ 11: 8-9.

GRANT, A. 1988. Animal resources, in Astill \& Grant (ed.): 149261.

HALLAM, H. (ed.). 1988a. The agrarian history of England and Wales II: 1042-1350: Cambridge: Cambridge University Press.

1988b. Farming techniques: Eastern England, in Hallam (ed.): $272-312$.

HanaWalt, B. 1986. The ties that bound. Peasant families in medieval England. Oxford \& New York (NY): Oxford University Press.

HaRVEY, S. 1988. Domesday England, in Hallam (ed.): 45-136.

LAUWERIER, R \& B. GROENEWOUDT. Forthcoming. Ritual and economics in fourth-century Heeten (the Netherlands), in S. Geraghty (ed.), Ethnography, history and environmental archaeology. Proceedings of the 18 th annual conference of the Association for Environmental Archaeology, Limerick September 1997.

LuFF, R, \& M. MORENO GARCIA. 1995. Killing cats in the medieval period. An unusual episode in the history of Cambridge, England, Archaeofauna 4: 93-114.

MCCORMICK, F. 1988. The domesticated cat in early Christian and Medieval Ireland, in G. Mac Niocaill \& P. Wallace (ed.), Keimelia: studies in Medieval archaeology and history in memory of Tom Delaney: 218-28. Galway: University Press.

In press. Dividing the carcass: the Irish evidence, in Miracle \& Milner (ed.).

Miracle, P. \& N. Milner (ed.). In press. Consuming passions and patterns of consumption. Cambridge: McDonald Institute.

Morris, J. 1984. Domesday book. A survey of the counties of England. Chichester: Phillimore.

NoddLE, B. 1977. Mammal bones, in H. Clarke \& A. Carter, Excavations in King's Lynn 1963-1970: 378-99. London: Society for Medieval Archaeology.

1980. Identification and interpretation of the mammal bones, in P. Wade-Martins, North Elmham Park vol. II, East Anglian Archaeology 9: 377-409.

Postan, M. 1973. Essays on medieval agriculture and general problems of the medieval economy. Cambridge: Cambridge University Press.

REDSTONE, V. 1931. The household book of Dame Alice de Bryene of Acton Hall, Suffolk, Sept. 1412-Sept. 1413. Ipswich: Harrison.

SERIEANTSON, D, 1989. Animal remains and the tanning trade, in D. Serjeantson \& T. Waldron (ed.), Diet and crofts in towns: the evidence of animal remains from the Roman to the Post-Medieval periods: 129-46. Oxford: British Archaeological Reports. British series 199.

TRIGG, S. (ed.). 1990. Wynnere and Wastoure. Oxford: Oxford University Press.

TRow-SMith, R. 1957. A history of British livestock husbandry to 1700. London: Routledge \& Kegan Paul.

WILSON, B. \& P. EDWARDS. 1993. Butchery of horse and dog at Witney Palace, Oxfordshire, and the knackering and feeding of meat to hounds during the post-medieval period, Post-Medieval Archaeology 27: 43-56. 